Entry

\title{
Greek Honey Authentication: Botanical Approach
}

\author{
Marinos Xagoraris ${ }^{1}(\mathbb{D})$, Panagiota-Kyriaki Revelou ${ }^{1,2} \mathbb{D}$, Eleftherios Alissandrakis ${ }^{3,4}$ (D), Petros A. Tarantilis ${ }^{1} \mathbb{D}$ \\ and Christos S. Pappas $1, *$ (D)
}

1 Laboratory of Chemistry, Department of Food Science and Human Nutrition, Agricultural University of Athens, 75 Iera Odos, 11855 Athens, Attica, Greece; mxagor@aua.gr (M.X.); p.revelou@aua.gr (P.-K.R.); ptara@aua.gr (P.A.T.)

2 Department of Food Science and Technology, University of West Attica, Ag. Spyridonos str, Egaleo, 12243 Athens, Attica, Greece

3 Laboratory of Quality and Safety of Agricultural Products, Landscape and Environment, Department of Agriculture, Hellenic Mediterranean University, Stavromenos PC, 71410 Heraklion, Crete, Greece; ealiss@hmu.gr

4 Institute of Agri-Food and Life Sciences Agro-Health, Hellenic Mediterranean University Research Center, Stavromenos PC, 71410 Heraklion, Crete, Greece

* Correspondence: chrispap@aua.gr; Tel.: +30-2105294262

check for updates

Citation: Xagoraris, M.; Revelou, P.-K.; Alissandrakis, E.; Tarantilis, P.A.; Pappas, C.S. Greek Honey Authentication: Botanical Approach. Encyclopedia 2021, 1, 1322-1333. https://doi.org/10.3390/ encyclopedia1040099

Academic Editors: Fabrizio Araniti

Received: 8 November 2021

Accepted: 17 December 2021

Published: 20 December 2021

Publisher's Note: MDPI stays neutral with regard to jurisdictional claims in published maps and institutional affiliations.

Copyright: (c) 2021 by the authors. Licensee MDPI, Basel, Switzerland. This article is an open access article distributed under the terms and conditions of the Creative Commons Attribution (CC BY) license (https:/ / creativecommons.org/licenses/by/ $4.0 /)$.
Definition: Honey is a functional, honeybee product with a useful role in human nutrition and several health benefits. Greece is a Mediterranean region with several types of monofloral honey. Today, Greek honey has acquired an important position in national and international markets. Due to this increased industrialization and globalization, quality control is a necessity. Mislabeling constitutes one of the most notable types of fraudulence, while most consumers are looking for authentic honey. Moreover, producers and suppliers are searching for rapid and analytical methodologies to secure Greek honey in a competitive environment. In this context, we aimed to describe the classical (melissopalynological, physicochemical) and analytical (chromatographic, spectrometric, and spectroscopic) methods for the standardization of the botanical origin of Greek honey.

Keywords: Greek honey; authentication; melissopalynology; physicochemical; chromatography; spectroscopy

\section{Introduction and Research Field}

Honeybees are an important group of insect pollinators; while they produce various bee products, honey is the most well-known. Since ancient times, honey constitutes the only sweetening product that can be stored and used exactly as produced in nature, a fact that makes it very important in terms of its authenticity. Practically, all types of honey are authentic and only human activity can affect them.

From a legal viewpoint, the European council directive (2001/110/EC) [1] defines honey as, "the natural sweet substance produced by Apis mellifera L. bees from the nectar of plants of from secretions of living parts of plants or excretions of plant-sucking insects on the living parts of plants, which the bees collect transform by combining with specific substances of their own, deposit, dehydrate, store and leave in honeycombs to ripen and mature". Additionally, composition criteria including physicochemical characteristics according to main types of origin (blossom or honeydew), production, and/or presentation (comb, chunk, drained, extracted, pressed, filtered, and baker's honey).

According to the literature during 1963-2017, in countries around the Mediterranean Basin, a total of 336 species of wild bees and honeybees and 54 beekeeping plants families were approximately estimated [2]. Greece is mainly inhabited by four common Apis mellifera L. subspecies namely A.m. cecropia in central and southern Greek mainland, A.m. carnica in Ionian Islands, A.m. adami in Crete and southern Aegean, and A.m. macedonica in Macedonia, Thrace, and parts of Thessaly and Epirus (Figure 1) [3]. 


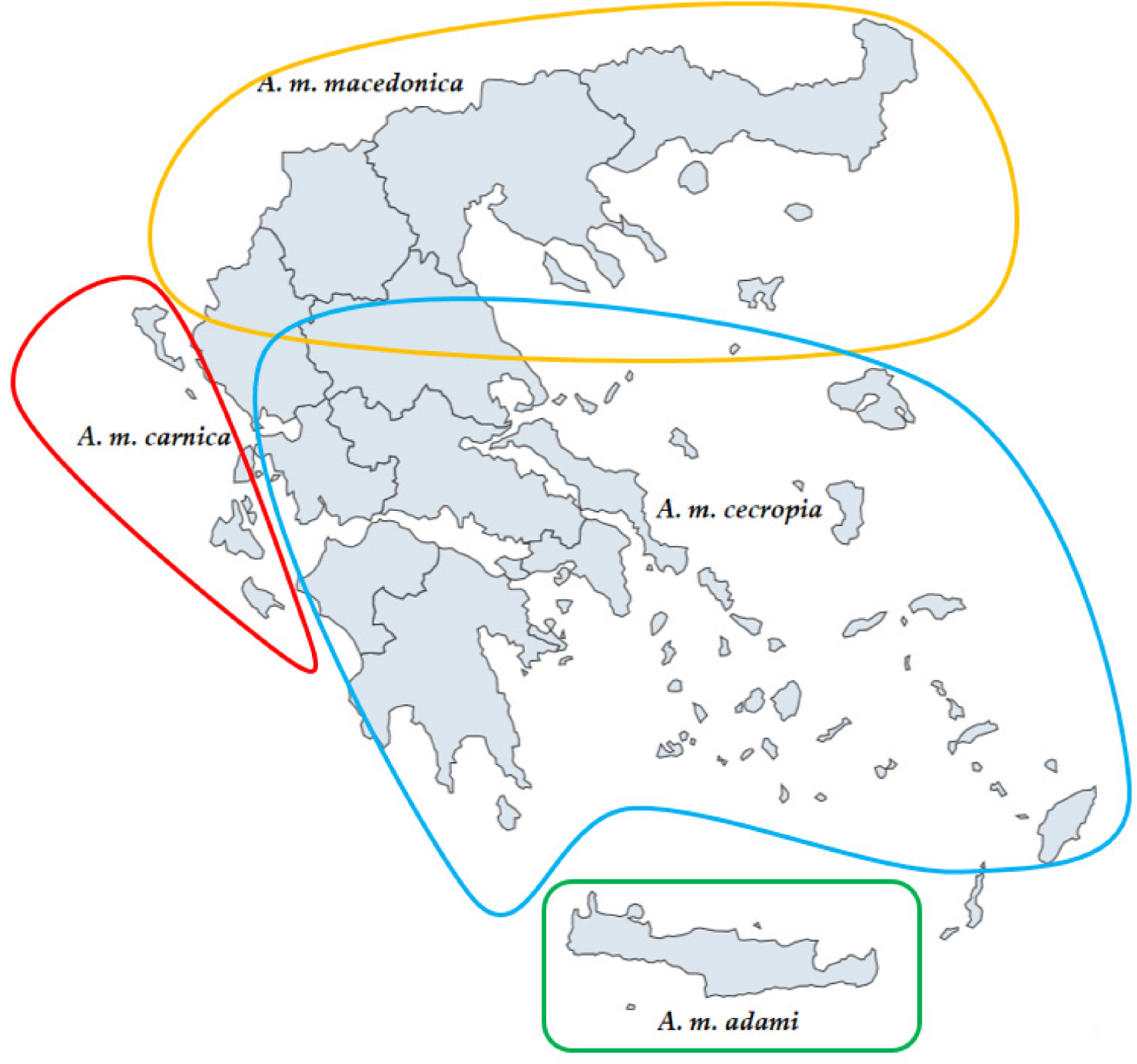

Figure 1. Four common Apis mellifera L. subspecies in the Greek region.

Beekeeping plants provide nectar, honeydew, and/or pollen to honeybees. "Blossom honey" is produced from flower nectar, while "honeydew honey" is from honeydew secretions from insects parasitizing the plants; various mixtures are also produced. The period when a plant provides food is called the "flowering period". Greece has a wide variety of indigenous and nonindigenous melliferous plants. The most common botanical species producing monofloral honeys in Greece are included in Table 1. Greek legislation has set more strict criteria (Table 2) compared to the European legislation regarding the eight most common monofloral honeys [4].

Today, most consumers are looking for authentic foods [5]. This growing demand is directly connected with market globalization, e-commerce, food chains, and national and international trade. In addition, due to strong economic motivations, more types of fraud are observed, including mislabeling and false declaration regarding origin (Figure 2). Food authentication according to the CEN Workshop Agreement 17,369:2019 is "a food product where there is a match between the actual food product characteristics and the corresponding food product claims; when the food product actually is that the claim says that is" [6]. Moreover, Codex Alimentarius described fraud as "any deliberate action of businesses or individuals to deceive others in regards to the integrity of food to gain undue advantage" [7]. 
Table 1. Melliferous species and honeys in Greek region.

\begin{tabular}{|c|c|c|c|c|c|c|}
\hline Scientific Name & Flowering Period & Nectar & Pollen & Honeydew & Honey Name & $\begin{array}{c}\text { Commercially } \\
\text { Widespread }\end{array}$ \\
\hline \multicolumn{7}{|c|}{ Blossom Honeys } \\
\hline Arbutus unedo L. & November-December & $3 *$ & 2 & - & Strawberry tree & $+* *$ \\
\hline Castanea sativa Miller & June & $2-3$ & 3 & $1-2$ & Chestnut & ++ \\
\hline Ceratonia siliqua $\mathrm{L}$. & September-October & 3 & 3 & 2 & Carob & + \\
\hline Citrus spp. & March-April & 3 & 2 & - & Citrus, orange etc. & ++ \\
\hline Erica arborea $\mathrm{L}$. & October-November & $2-3$ & $2-3$ & - & Spring Heather & ++ \\
\hline $\begin{array}{l}\text { Erica manipuliflora } \\
\text { Salisb. }\end{array}$ & March & 3 & $2-3$ & - & Autumn Heather & ++ \\
\hline Eucalyptus spp. & May-July & $2-3$ & $2-3$ & - & Eucalyptus & + \\
\hline Gossypium hirsutum L. & July-September & & - & - & Cotton & ++ \\
\hline Helianthis annuus L. & June-August & $2-3$ & $2-3$ & - & Sunflower & + \\
\hline $\begin{array}{l}\text { Paliurus spina-christi } \\
\text { Miller }\end{array}$ & May-June & $2-3$ & 2 & - & Jerusalem thorn & + \\
\hline Phlomis spp. & & $2-3$ & - & - & Jerusalem sage & + \\
\hline Pimpinella anisum $\mathrm{L}$. & & $1-2$ & $1-2$ & - & Anise & + \\
\hline Polygonum aviculare $\mathrm{L}$. & July-August & 2 & 2 & - & $\begin{array}{l}\text { Common } \\
\text { knotweed }\end{array}$ & + \\
\hline Salvia officinalis L. & & $2-3$ & 2 & - & Sage & + \\
\hline Thymbra capitata L. & June-July & $2-3$ & 2 & - & Thyme & +++ \\
\hline \multicolumn{7}{|c|}{ Honeydew Honeys } \\
\hline Abies cephalonica Link. & May-July & - & - & 3 & Fir & ++ \\
\hline Pinus spp. & $\begin{array}{l}\text { March-April, } \\
\text { June-August, } \\
\text { September-October }\end{array}$ & - & - & 3 & Pine & +++ \\
\hline Quercus spp. & & - & 3 & 3 & Oak & + \\
\hline
\end{tabular}

* Number 1: low contribution; number 2: medium contribution; number 3: high contribution; dash (-): no contribution. ${ }^{* *}$ high (+++), medium $(++)$, and low $(+)$ commercially widespread.

Table 2. Greek legislation criteria of eight common monofloral honeys.

\begin{tabular}{|c|c|c|c|c|c|c|c|c|}
\hline & Pine & Fir & Chestnut & Heather & Thyme & Citrus & Cotton & Sunflower \\
\hline Moisture (\%) & - & $\leq 18.5$ & - & - & - & - & - & - \\
\hline $\begin{array}{l}\text { Electrical conductivity } \\
\left(\mathrm{Ms} \mathrm{cm}^{-1}\right)\end{array}$ & $\geq 0.9$ & $\geq 1.0$ & $\geq 1.1$ & - & $\leq 0.6$ & $\leq 0.45$ & - & - \\
\hline $\begin{array}{l}\text { Main pollen (\%) of pollen } \\
\text { of nectar plants }\end{array}$ & - & - & $\geq 87$ & $\geq 45$ & $\geq 18^{*}$ & $\geq 3$ & $\geq 3$ & $\geq 20$ \\
\hline $\mathrm{HDE} / \mathrm{P} * *$ & varies & varies & - & - & - & - & - & - \\
\hline \multirow[t]{2}{*}{ TPG $/ 10 \mathrm{~g} * * *$} & varies & varies & $\geq 100,000$ & - & $<90,000$ & $<70,000$ & $<90,000$ & $<55,000$ \\
\hline & $\begin{array}{c}\text { major } \\
\text { presence of } \\
\text { characteris- } \\
\text { tic } \\
\text { honeydew } \\
\text { elements }\end{array}$ & $\begin{array}{c}\text { minor } \\
\text { presence of } \\
\text { characteris- } \\
\text { tic } \\
\text { honeydew } \\
\text { elements }\end{array}$ & - & - & - & - & - & - \\
\hline
\end{tabular}

${ }^{*}$ The percentage of accompanying pollen grains of a plant species should not exceed $45 \%$. ${ }^{* *}$ Honeydew elements $/$ pollen. ${ }^{* * *}$ Total number of pollen grains. 


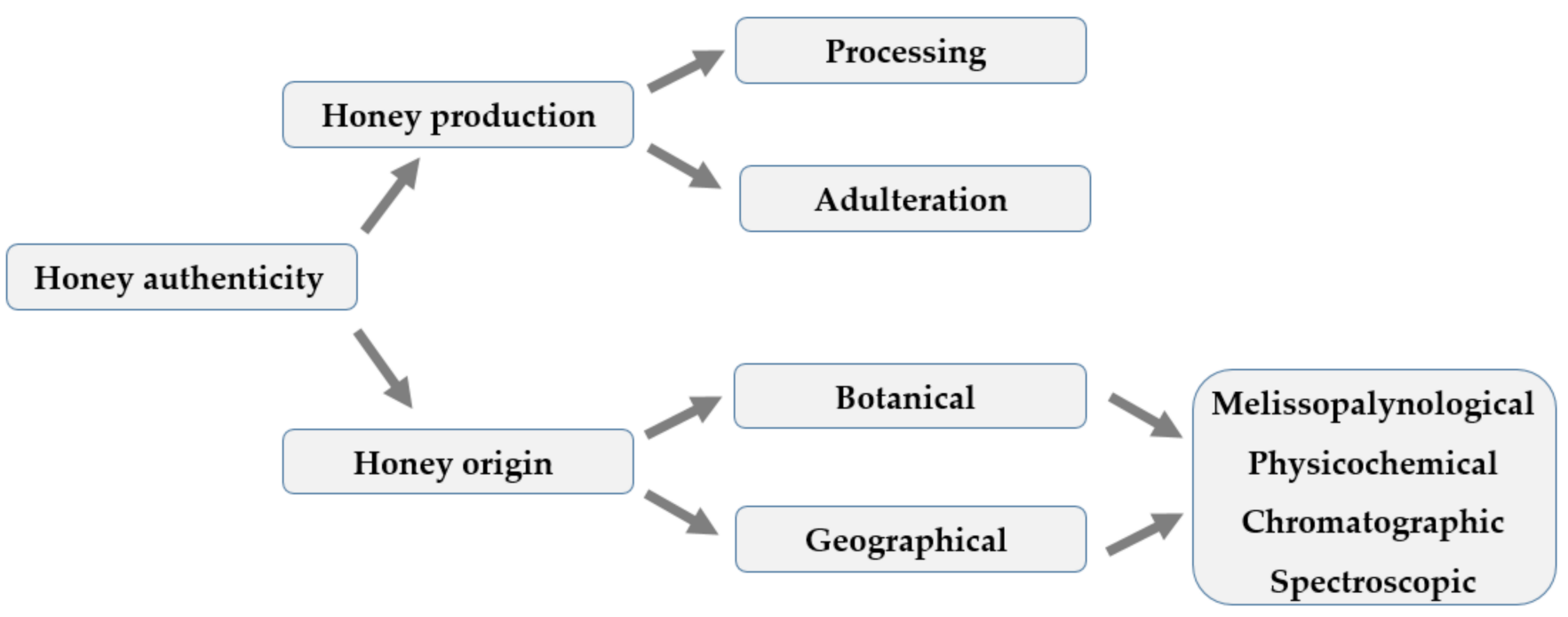

Figure 2. A summary of the honey authenticity fields.

The notion of honey authenticity has received great interest worldwide and increased focus in the last twenty years. However, prior to the commentary of the honey authenticity techniques one must distinguish the concept of "honey quality", "honey standardization", and "honey packaging" (Figure 3). Honey quality is a summary of characteristics that are considered important for determining the degree of acceptance by the consumer. Honey standardization is the process by which specifications are established of its production, the composition, and the properties. Finally, the packaging is their placement inside a packaging material to be protected from physical, chemical, and biological hazards and to be transported.

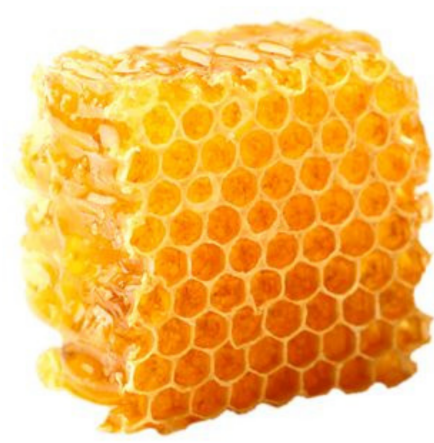

Honey quality

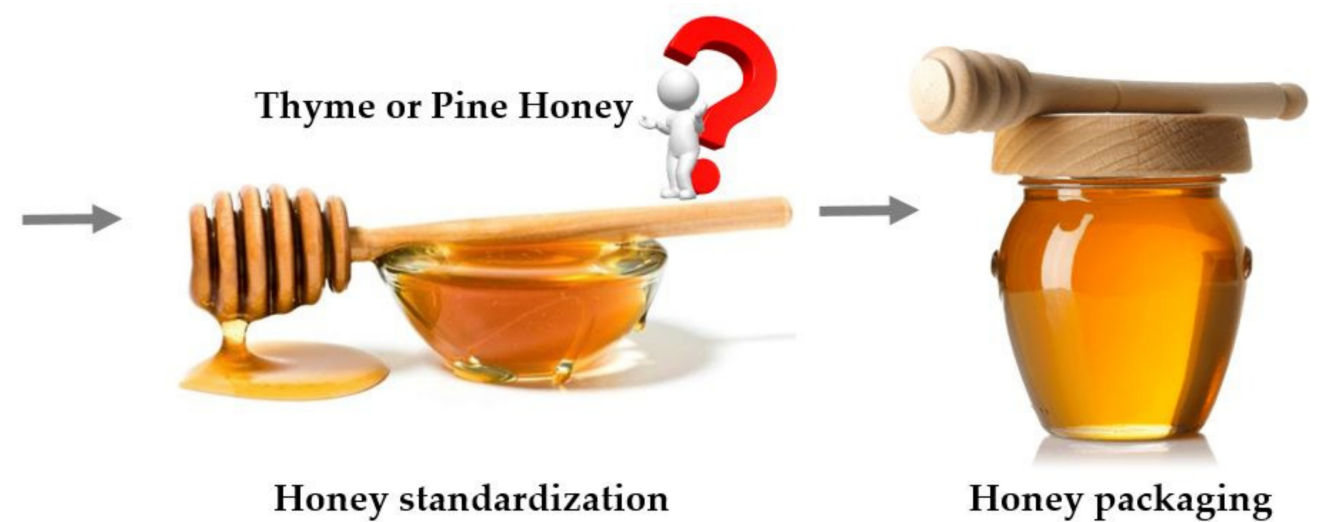

Figure 3. From "honey quality" to "honey packaging".

According to the Scopus database, the most studied authenticity issue is the honey botanical origin differentiation. From reviewing, the most frequent analytical methods of honey botanical discrimination are classical and instrumental chemistry analyses. However, emphasis was given to specific botanical markers and/or in representative "fingerprint" spectra. Table 3 gives an overview of the most ordinary methods for honey authentication. 
Table 3. A summary of the methods for the botanical differentiation of honey.

\begin{tabular}{|c|c|c|}
\hline Analytical Technique & Abbreviation & Main Analytes and Parameters \\
\hline \multicolumn{3}{|c|}{ Melissopalynological and Physicochemical techniques } \\
\hline Optical microscopy & $\mathrm{OM}$ & \multirow{2}{*}{ Pollen analysis } \\
\hline Scanning Electron Microscope & SEM & \\
\hline Conductimetry & & Electrical conductivity \\
\hline Refractometer & & Moisture \\
\hline \multirow{2}{*}{ Colorimetry-Photometry } & & Diastase (Heat abuse) \\
\hline & & $\begin{array}{l}\text { Hydroxymethylfurfural (HMF) (Heat } \\
\text { abuse) }\end{array}$ \\
\hline Potentiometry & & Acidity \\
\hline $\begin{array}{l}\text { International commission on } \\
\text { Illumination }\end{array}$ & CIE & Lightness, color, hue \\
\hline Viscometer & & Rheological properties \\
\hline \multicolumn{2}{|l|}{$\mathrm{pH}$-meter } & $\mathrm{pH}$ \\
\hline \multicolumn{3}{|c|}{ Chromatographic techniques } \\
\hline \multirow{2}{*}{$\begin{array}{c}\text { High-Performance Liquid } \\
\text { Chromatography Diode-Array } \\
\text { Detector }\end{array}$} & \multirow{2}{*}{ HPLC-DAD } & Hydroxymethylfurfural (HMF) \\
\hline & & Phenolics \\
\hline $\begin{array}{c}\text { High-Performance Liquid } \\
\text { Chromatography Refractive Index } \\
\text { Detector }\end{array}$ & HPLC-RID & Sugars \\
\hline \multirow{2}{*}{$\begin{array}{c}\text { High-Performance Liquid } \\
\text { Chromatography Fluorescence } \\
\text { Detector }\end{array}$} & \multirow{2}{*}{ HPLC-FS } & Amino acids \\
\hline & & Phenolics \\
\hline $\begin{array}{l}\text { High-Performance Liquid } \\
\text { Chromatography Pulsed } \\
\text { Amperometric Detector }\end{array}$ & HPLC-PAD & Sugars \\
\hline \multirow{4}{*}{$\begin{array}{l}\text { High-Performance Thin-Layer } \\
\text { Chromatography }\end{array}$} & \multirow{4}{*}{ HPTLC } & Phenolics \\
\hline & & Non-volatile components \\
\hline & & Sugars and/or fructose/glucose ratio \\
\hline & & Hydroxymethylfurfural (HMF) \\
\hline \multirow{2}{*}{$\begin{array}{l}\text { Liquid Chromatography Mass } \\
\text { Spectrometry }\end{array}$} & \multirow{2}{*}{ LC-MS } & Hydroxymethylfurfural (HMF) \\
\hline & & Phenolics \\
\hline \multirow{2}{*}{$\begin{array}{l}\text { Gas Chromatography Mass } \\
\text { Spectrometry }\end{array}$} & \multirow{2}{*}{ GC-MS } & Volatiles \\
\hline & & Semi-volatiles \\
\hline \multicolumn{3}{|c|}{ Spectroscopic techniques } \\
\hline Ultraviolet-Visible Spectroscopy & UV-Vis & Spectrum of phenolics \\
\hline Raman Spectroscopy & Raman & $\begin{array}{l}\text { Sugars spectra and minor } \\
\text { components }\end{array}$ \\
\hline $\begin{array}{l}\text { Fourier-Transform Mid-Infrared } \\
\text { Spectroscopy }\end{array}$ & FT-MIR & $\begin{array}{l}\text { Sugars spectra and minor } \\
\text { components }\end{array}$ \\
\hline $\begin{array}{l}\text { Fourier-Transform Near-Infrared } \\
\text { Spectroscopy }\end{array}$ & FT-NIR & $\begin{array}{l}\text { Sugars spectra and minor } \\
\text { components }\end{array}$ \\
\hline Fluorescence Spectroscopy & FS & $\begin{array}{l}\text { Spectra of amino acids, phenolics, } \\
\text { Maillard reaction by-products }\end{array}$ \\
\hline Nuclear Magnetic Resonance & NMR & $\begin{array}{l}\text { Sugars, untargeted and targeted } \\
\text { screening }\end{array}$ \\
\hline
\end{tabular}


Table 3. Cont.

\begin{tabular}{ccc}
\hline Analytical Technique & Abbreviation & Main Analytes and Parameters \\
\hline & Other techniques & \\
\hline $\begin{array}{c}\text { Isotope-Ration Mass Spectrometry } \\
\text { Inductively Coupled Plasma Mass } \\
\text { Spectrometry }\end{array}$ & IRMS & $\begin{array}{c}\text { Isotope ration of H, C, N, S, and /or } \\
13 \mathrm{C} \text { ratios }\end{array}$ \\
\hline
\end{tabular}

\section{Harvest, Honey Identity, and Authenticity Issues}

\subsection{Honey Harvesting}

Honey harvesting is the most significant step before any further analysis. Honey is primarily a concentrated solution of sugars with other compounds such as organic acids, enzymes, vitamins, minerals, phenolics, and volatiles [8].

Honey composition is dependent on the plants that honeybees visit. Most beekeepers know the floral sources from which their honeybees collect nectar and pollen. This is because they consciously choose the flowering period and location of the hive. However, some beekeepers move the hives to more than one area in order to collect nectar sources from a wider area. In those cases, multifloral honey is produced. In addition, honey composition can be affected by beekeeper's manipulations, postharvest processing [9], and storage conditions and length [10]. After harvesting, honey is subjected to various postharvest processing steps including extraction and sometimes dehumidification, liquefaction, heating, or pasteurization [11]. Finally, packaged honey must remain under cool and shady conditions before further use.

\subsection{Classical Methods for Honey Authentication}

Generally, melissopalynology is a microscopic analysis of honey and it is the basic method for determination of their botanical origin. Blossom honeys are considered mainly from one or more sources of pollen grains. According to legislation criteria, when the pollen content is over- or under-represented, honey can be characterized as unifloral or polyfloral. In addition, for honeydew honeys, the ratio of honeydew elements/pollen $(\mathrm{HDE} / \mathrm{P})$ is taken into account for botanical determination. Melissopalynological analysis constitutes a classic and widely used method for detecting botanical origin of Greek honey [12-18]. Tsigouri et al. [15] gave some palynological characteristics of 208 different monofloral honeys including fir, pine, chestnut, cotton, citrus, and thyme. Karabournioti et al. [13] carried out melissopalynological analysis in 135 thyme honeys and quantitated 65,000 pollen grains per $10 \mathrm{~g}$ of thyme honeys. More recently, Rodopoulou et al. [17] applied microscopic analysis to determine the botanical origin of thyme honeys, while they investigated the effects of over-presented pollen grains in blend honeys. However, they concluded that in some cases pollen analysis did not give trustworthy results and should be combined with other analyses. Recently, Tsiknakis et al. [18] applied machine learning to classify Cretan pollen grains with overall detection accuracy of $92 \%$.

Pollen grains come mainly from the plants foraged by honeybees, while these pollens provide the botanical origin [19]. However, melissopalynological analysis requires specialized staff with experience in pollen grain recognition. Furthermore, this analysis always needs literature on beekeeping plants and optical or a scanning microscope for greater accuracy. Moreover, the possibility of human error is high with subjectivity in the entire process. Fraudulent counterfeiting actions, such as removing existing pollen and replacing it with another, could alter pollen content.

Reviewing the literature, many studies were based on physicochemical analyses to discriminate monofloral Greek honeys [12,16,17,20-22]. In most cases, physicochemical analyses showed a good success rate in classifying honey. Generally, honeydew honey is characterized by higher values of electric conductivity and acidity compared to blossom honey. On the other hand, blossom honey is richer in monosaccharides, and lighter colored. 
Further, physicochemical analyses as defined by Greek legislation provide information for quality (moisture must be lower than $20 \% w / w$ ), freshness (diastase not lower than 8 Schade and HMF not higher than $40 \mathrm{mg} / \mathrm{kg}$ ), stability, and shelf life of honey. Even so, sporadically, the dispersion of the above values, associated with the nature and heterogeneity of honey produces overlapping and reduces their usefulness. Physicochemical analyses overall are time-consuming and non-environmentally friendly techniques. In addition, they require large quantities of honey, a lot of chemical reagents, and trained labor. Even so, physiochemical analyses are a valuable reference and officially recognized methods and are widely used for the evaluation and characterization of blossom and honeydew honey, usually providing accurate and reliable results.

\subsection{Analytical Methods for Honey Authentication}

\subsubsection{Chromatographic Techniques}

Chromatographic techniques, including mainly LC and GC, are the most commonly used methodologies for honey authentication. These analytical techniques can be coupled with many detectors for qualitative or quantitative analysis of several compounds. A variety of methods have been developed during the last 20 years to meet with the demand for reliable certification of monofloral honey.

Prior to LC analysis, extraction of target compounds is carried out including sugars, phenolic compounds, amino acids, and other molecules. Phenolic compounds are present in all honeys and largely dependent on the botanical origin, while some of them come from bee propolis. Amino acids originate mainly from pollen resulting in high variability between different floral kinds of honey. As a result, depending on the extraction method and the polarity of solvents, a different fraction of compounds is isolated each time. However, this selective extraction is an important piece of research that can give different results. LC has been used to differentiate Greek monofloral honeys [23-25]. Initially, interest was focused on the separation and identification of phenolic compounds of commercial Greek pine, thyme, and fir honey [26,27]. Then, classification efforts were carried out with an overall rate of $99.2 \%$ [24]. Recently, a study characterized the phenolic profile on ten different honey botanical origins by a targeted and untargeted analysis [25]. The main advantage of the above technique is that it allows simultaneous measurement of several compounds in one analysis. Nevertheless, sample isolation procedures, which are often regarded as time-consuming, are needed. In addition, an LC system is expensive and complex.

Numerous studies have been carried out in the last years to evaluate GC analysis in the separation and quantification of volatiles and semi-volatiles. These volatile organic compounds (VOCs) originate from source plants, while some of them are transformed by honeybees or processes like heating and storage. Furthermore, VOCs analytes are dependent on isolation techniques and solvents. Compounds with high volatility isolated by solid-phase micro extraction (SPME) and semi-volatiles in most cases by liquid-liquid extraction (LLE), ultrasound extraction (USE), and solid phase extraction (SPE) using nonpolar solvents. Almost exclusively, GC was combined with MS detectors in order to identify the isolated compounds. Alissandrakis et al. [28] used ultrasound-assisted extraction for isolation and relation volatiles and semi-volatiles from citrus honeys and citrus flowers. Thus, GC-MS analysis indicated associations that are mainly due to linalool derivatives. Two years later, Alissandrakis et al. [29] determined a total of 15 volatile compounds that could serve as potent markers for cotton honey. Later on, the determination of volatile compounds based on SPME coupled with GC-MS was adopted to investigate the dominant volatile fraction of Greek citrus and thyme honey [30,31]. In the same period, Tananaki et al. [32] analyzed 22 samples of pine honey from the Greek region and determined their characteristic volatiles. Then, GC-MS was applied for the botanical discrimination of 77 monofloral honeys (chestnut, cotton, fir, heather, pine, thyme, and citrus) [33] with correct classification of samples higher than $98 \%$, while Karabagias et al. [21] tried to classify fir, thyme, pine, and orange honeys with an overall rate of $84.0 \%$. In a more recent study, the volatile fraction of some common and rare honeys by a non-targeted 
metabolomics methodology using GC-MS was studied [34] using SPME-GC-MS, while later, 151 honeys were classified into seven groups (clover, citrus, chestnut, eucalyptus, fir, pine, thyme) based on 56 volatile compounds with classification rate of $95.4 \%$ using the SPME technique [35]. Xagoraris et al. [36-38] identified key volatiles compounds which were directly associated with the botanical origin of Greek honey (thyme, pine, fir, citrus, heather) and will enable the development of analytical methods based on GC-MS for application in industrial setting for botanical honey authentication. Furthermore, the interest has been focused on rare honey varieties such as strawberry tree honey [39]. GC constitutes a suitable technique with high resolution and reproducibility. However, as in the case of LC, it needs skilled operators and the whole system is expensive.

Following the above chromatographic techniques, multivariate statistical analysis in combination with LC and GC analytical data could be a powerful tool for botanical authentication of honey. These statistical tools can be more powerful when combined with internal and external validation sets to enhance the robustness of the proposed chemometric models and could be used by industry.

\subsubsection{Spectroscopic Techniques}

UV-Vis, FTIR, Raman, FS, and NMR have been proposed as rapid methods for honey authentication. They provide information of honey fingerprint and can be used for routine analysis. However, only a few studies have evaluated their potential to determinate the botanical origin of Greek monofloral honey.

UV-Vis (200-900 nm) is a traditional spectroscopic technique and this region of absorbance has been related to various compounds such as phenolics and sugars (mainly glucose and fructose). Orfanakis et al. [40] based on UV absorption (200-400 nm) classified blossom and honeydew honeys with a successful estimation of $92.65 \%$ and $91.30 \%$, respectively. This result showed that UV spectroscopy can provide an alternative approach to determine the botanical origin of honey.

Mid FTIR (4000-400 $\mathrm{cm}^{-1}$ ), especially combined with Attenuated Total Reflection (ATR), is a well-establish technique recording the vibration bonds of water, sugars, phenolics, carboxylic acids, and amino acids. However, Mid FTIR have the inability to measure compounds with very low concentrations and difficulty in samples with high presentence in water, due to the strong O-H absorption. Honey FTIR spectra consist of a region between 4000 and $1500 \mathrm{~cm}^{-1}$ attributed to functional groups and a region between 1500 and $750 \mathrm{~cm}^{-1}$ attributed to sugars and is known as a honey "fingerprint". Orfanakis et al. [40] developed a chemometric model with correct classification rate of $95.56 \%$ and $100 \%$ for multifloral and thyme honeys, respectively, based on FTIR region between 4000 and $2400 \mathrm{~cm}^{-1}$. In addition, in a previous study, a chemometric model was developed based on $847-803$ and $1390-945 \mathrm{~cm}^{-1}$ spectral regions with a classified rate of $93 \%$ [36]. These monofloral honey samples from four botanical origins (thyme, pine, fir, citrus) were crossvalidated with a successful percentage of $82.3 \%$, while external validation identified correctly $84.6 \%$ of test set samples [36].

Raman spectroscopy is a simple technique used to study vibrational, rotational, and other low frequency models in a sample such as honey. Moreover, Raman spectra are not affected by the presence of water, constituting an advantage compared to FTIR. However, this analytical technique has barely been studied in evaluation in Greek honey authentication. A recent study proposed a chemometric model for the discrimination of botanical origin of three (thyme, pine, fir) Greek common honeys [16]. The developed model estimates a recognition of standards of $95.3 \%$, whilst cross-validation and external validation were $90.6 \%$ and $84.3 \%$, respectively [16].

FS (electronic transition $S_{1} \rightarrow S_{0}$ with timescale of $10^{-9}$ to $10^{-6}$ ) is rapid and 100-1000 times more sensitive than other spectroscopic techniques. FS spectra are often complicated due to Raman and/or Rayleigh scattering. To avoid scattering, Front-Face Fluorescence (FFS) or Synchronous Fluorescence Spectroscopy (SFS) can be applied. However, it is not necessary that the above scattering affect the spectral area which was investigated. Thus, 
right-angle fluorescence spectroscopy can be used. Honey contains intrinsic fluorochrome compounds, including phenolics, flavins, Maillard reaction products, and amino acids. An alternative novel method, based on hydroxycinnamic and other phenyl carboxylic acids, was developed to evaluate the potential of right-angle fluorescence to distinguish and determine the botanical origin of four Greek honey samples (thyme, pine, fir, citrus) [41]. All chemometric models were considered successful and they can be used for routine analysis.

NMR has achieved general acceptance because of its noninvasive characteristics in honey analysis. However, the above technique produces a very complex spectra, with much information mainly for sugar profile. The NMR profile of Greek honey was investigated previously by some studies [42,43]. Nevertheless, to the best of our knowledge, no study using NMR spectroscopy has been performed for Greek honey authentication.

During the last years, spectroscopic methods have become increasingly practicable as a novel application for determining the botanical origin of honey. They have many advantages including high simplicity, speed, repeatability, and accuracy, while they are environmentally friendly, nondestructive, and noninvasive for the samples. In this context, more research is required on their application in botanical differentiation of Greek honey.

\subsubsection{Other Analytical Techniques}

Mineral content can be identified by ICP analysis combined with MS or Optical Emission Spectrometry (OES). Nevertheless, the profile of mineral content can give information mainly for geographical origin [44-47] and secondarily for botanical origin [22,48] of Greek honey samples.

Other alternative techniques such as Laser Induced Breakdown Spectroscopy (LIBS) [49] and Stable Isotope Ratio MS (IRMS) [50] have been also investigated for their potential as analytical tools for honey authentication. However, all the above techniques must be combined with chemometric tools to extract their information from the data sets.

\section{Conclusions}

To summarize, the authenticity of Greek honey has acquired increasing interest from consumers, producers, suppliers, and therefore scientists. These increasing demands push the adoption of legislation criteria that will be imposed on honey suppliers worldwide. However, the current melissopalynological and physicochemical criteria are complex, allowing the mislabeling of botanical origin. In recent years, chemometric models based on synchronous chromatographic and spectroscopic techniques have been efficiently used. These techniques include among others, LC, GC, UV-Vis, FTIR, Raman, FS, NMR, ICP, LIBS, and IRMS. Chromatography could be used as a screening tool, while many studies dealt with phenolics and VOCs as potential botanical markers of monofloral Greek honey. Spectroscopy as an application tool is rapid, relatively low-cost, environmentally friendly, and can be applied in both industries and/or fundamental research monitoring the botanical determination of Greek honey.

Author Contributions: Conceptualization, M.X.; writing—original draft preparation, M.X.; writingreview and editing, P.-K.R., E.A., P.A.T., and C.S.P.; supervision, C.S.P. All authors have read and agreed to the published version of the manuscript.

Funding: This research received no external funding.

Institutional Review Board Statement: Not applicable.

Informed Consent Statement: Not applicable.

Data Availability Statement: Not applicable.

Conflicts of Interest: The authors declare no conflict of interest.

Entry Link on the Encyclopedia Platform: https://encyclopedia.pub/18582 


\section{References}

1. EU. Council Directive 2001/110/EC of 20 December 2001 Relating to Honey. Off. J. Eur. Communities 2002, 10, 47-52. Available online: https:/ / eur-lex.europa.eu/LexUriServ/LexUriServ.do?uri=OJ:L:2002:010:0047:0052:EN:PDF (accessed on 6 November 2021).

2. Herrera, C.M. Gradual replacement of wild bees by honeybees in flowers of the Mediterranean Basin over the last 50 years. Proc. R. Soc. B Biol. Sci. 2020, 287. [CrossRef] [PubMed]

3. Ruttner, F. Biogeography and Taxonomy of Honeybees; Springer: Berlin/Heidelberg, Germany, 1988; ISBN 978-3-642-72651.

4. Government Gazette B-239/23-2-2005 Annex II Article 67 of Greek Food Code. 2005. Available online: http:/ / www.minagric.gr / images/stories/docs/agrotis/MeliMelissokomia/KYA_Taytopoiisi_.pdf (accessed on 6 November 2021).

5. Karoui, R. Food Authenticity and Fraud. In Chemical Analysis of Food: Techniques and Applications; Academic Press: Cambridge, MA, USA, 2012; pp. 499-517. ISBN 9780123848628.

6. CEN Workshop Agreement (CWA) 17369:2019-Authenticity and Fraud in the Feed and Food Chain-Concepts, Terms, and Definitions. Available online: https:/ / standards.cen.eu/dyn/www /f?p=204:110:0::::FSP_PROJECT,FSP_ORG_ID:68640,2273 736\&cs=1AE0F1E6D2455306ADD8460579462378C (accessed on 6 November 2021).

7. Codex Alimentarius-Discussion Paper on Food Integrity and Food Authenticity_-Joint FAO/WHO Food Standards Programme. Codex Committee on Food Import and Export Inspection and Certification Systems. Twenty-Fourth Session. Brisbane, Australia, 22-26 October 2018. CX/FICS 18/24/7. Available online: https://www.fao.org/fao-who-codexalimentarius/shproxy/en/?lnk= 1\&url=https $\% 253 \mathrm{~A} \% 252 \mathrm{~F} \% 252 \mathrm{Fw}$ orkspace.fao.org\%252Fsites $\% 252$ Fcodex $\% 252 \mathrm{FMeetings} \% 252 \mathrm{FCX}-733-24 \% 252 \mathrm{FWorking} \%$ 2BDocuments\%252Ffc24_07e.pdf (accessed on 6 November 2021).

8. Puścion-Jakubik, A.; Borawska, M.H.; Socha, K. Modern methods for assessing the quality of Bee Honey and botanical origin identification. Foods 2020, 9, 1028. [CrossRef]

9. Da Silva, P.M.; Gauche, C.; Gonzaga, L.V.; Costa, A.C.O.; Fett, R. Honey: Chemical composition, stability and authenticity. Food Chem. 2016, 196, 309-323. [CrossRef] [PubMed]

10. Visser, F.R.; Allen, J.M.; Shaw, G.J. The effect of heat on the volatile flavour fraction from a unifloral honey. J. Apic. Res. 1988, 27, 175-181. [CrossRef]

11. Baglio, E. Chemistry and Technology of Honey Production; Springer Briefs in Molecular Science; Springer International Publishing: Cham, Switzerland, 2018; ISBN 978-3-319-65749-3.

12. Thrasyvoulou, A.; Manikis, J. Some physicochemical and microscopic characteristics of Greek unifloral honeys. Apidologie 1995, 26, 441-452. [CrossRef]

13. Karabournioti, S.E.; Tsiripidis, I.; Thrasyvoulou, A.; Eleftheriou, E.P. Melissopalynological attributes of some Greek thyme honeys. J. Apic. Res. 2009, 48, 104-114. [CrossRef]

14. Dimou, M.; Tananaki, C.; Liolios, V.; Thrasyvoulou, A. Pollen foraging by honey bees (Apis Mellifera L.) in Greece: Botanical and geographical origin. J. Apic. Sci. 2014, 58, 11-23. [CrossRef]

15. Tsigouri, A.; Passaloglou-Katrali, M.; Sabatakou, O. Palynological characteristics of different unifloral honeys from Greece. Grana 2004, 43, 122-128. [CrossRef]

16. Xagoraris, M.; Lazarou, E.; Kaparakou, E.H.; Alissandrakis, E.; Tarantilis, P.A.; Pappas, C.S. Botanical origin discrimination of Greek honeys: Physicochemical parameters versus Raman spectroscopy. J. Sci. Food Agric. 2021, 101, 3319-3327. [CrossRef]

17. Rodopoulou, M.A.; Tananaki, C.; Dimou, M.; Liolios, V.; Kanelis, D.; Goras, G.; Thrasyvoulou, A. The determination of the botanical origin in honeys with over-represented pollen: Combination of melissopalynological, sensory and physicochemical analysis. J. Sci. Food Agric. 2018, 98, 2705-2712. [CrossRef] [PubMed]

18. Tsiknakis, N.; Savvidaki, E.; Kafetzopoulos, S.; Manikis, G.; Vidakis, N.; Marias, K.; Alissandrakis, E. Segmenting 20 types of pollen grains for the cretan pollen dataset v1 (CPD-1). Appl. Sci. 2021, 11, 6657. [CrossRef]

19. Von Der Ohe, W.; Oddo, L.P.; Piana, M.L.; Morlot, M.; Martin, P. Harmonized methods of melissopalynology. Apidologie 2004, 35, S18-S25. [CrossRef]

20. Rodopoulou, M.A.; Tananaki, C.; Kanelis, D.; Liolios, V.; Dimou, M.; Thrasyvoulou, A. A chemometric approach for the differentiation of 15 monofloral honeys based on physicochemical parameters. J. Sci. Food Agric. 2021, 102, 139-146. [CrossRef] [PubMed]

21. Karabagias, I.K.; Badeka, A.V.; Kontakos, S.; Karabournioti, S.; Kontominas, M.G. Botanical discrimination of Greek unifloral honeys with physico-chemical and chemometric analyses. Food Chem. 2014, 165, 181-190. [CrossRef]

22. Louppis, A.P.; Karabagias, I.K.; Kontakos, S.; Kontominas, M.G.; Papastephanou, C. Botanical discrimination of Greek unifloral honeys based on mineral content in combination with physicochemical parameter analysis, using a validated chemometric approach. Microchem. J. 2017, 135, 180-189. [CrossRef]

23. Karabagias, I.K. Seeking of reliable markers related to Greek nectar honey geographical and botanical origin identification based on sugar profile by HPLC-RI and electro-chemical parameters using multivariate statistics. Eur. Food Res. Technol. 2019, 245, 805-816. [CrossRef]

24. Karabagias, I.K.; Vavoura, M.V.; Nikolaou, C.; Badeka, A.V.; Kontakos, S.; Kontominas, M.G. Floral authentication of Greek unifloral honeys based on the combination of phenolic compounds, physicochemical parameters and chemometrics. Food Res. Int. 2014, 62, 753-760. [CrossRef] 
25. Koulis, G.A.; Tsagkaris, A.S.; Aalizadeh, R.; Dasenaki, M.E.; Panagopoulou, E.I.; Drivelos, S.; Halagarda, M.; Georgiou, C.A.; Proestos, C.; Thomaidis, N.S. Honey phenolic compound profiling and authenticity assessment using HRMS targeted and untargeted metabolomics. Molecules 2021, 26, 2769. [CrossRef]

26. Tsiapara, A.V.; Jaakkola, M.; Chinou, I.; Graikou, K.; Tolonen, T.; Virtanen, V.; Moutsatsou, P. Bioactivity of Greek honey extracts on breast cancer (MCF-7), prostate cancer (PC-3) and endometrial cancer (Ishikawa) cells: Profile analysis of extracts. Food Chem. 2009, 116, 702-708. [CrossRef]

27. Spilioti, E.; Jaakkola, M.; Tolonen, T.; Lipponen, M.; Virtanen, V.; Chinou, I.; Kassi, E.; Karabournioti, S.; Moutsatsou, P. Phenolic acid composition, antiatherogenic and anticancer potential of honeys derived from various regions in Greece. PLoS ONE 2014, 9 , e94860. [CrossRef]

28. Alissandrakis, E.; Daferera, D.; Tarantilis, P.A.; Polissiou, M.; Harizanis, P.C. Ultrasound-assisted extraction of volatile compounds from citrus flowers and citrus honey. Food Chem. 2003, 82, 575-582. [CrossRef]

29. Alissandrakis, E.; Kibaris, A.C.; Tarantilis, P.A.; Harizanis, P.C.; Polissiou, M. Flavour compounds of Greek cotton honey. J. Sci. Food Agric. 2005, 85, 1444-1452. [CrossRef]

30. Alissandrakis, E.; Tarantilis, P.A.; Harizanis, P.C.; Polissiou, M. Aroma investigation of unifloral Greek citrus honey using solid-phase microextraction coupled to gas chromatographic-mass spectrometric analysis. Food Chem. 2007, 100, 396-404. [CrossRef]

31. Alissandrakis, E.; Tarantilis, P.A.; Harizanis, P.C.; Polissiou, M. Comparison of the volatile composition in thyme honeys from several origins in Greece. J. Agric. Food Chem. 2007, 55, 8152-8157. [CrossRef] [PubMed]

32. Tananaki, C.; Thrasyvoulou, A.; Giraudel, J.L.; Montury, M. Determination of volatile characteristics of Greek and Turkish pine honey samples and their classification by using Kohonen self organising maps. Food Chem. 2007, 101, 1687-1693. [CrossRef]

33. Aliferis, K.A.; Tarantilis, P.A.; Harizanis, P.C.; Alissandrakis, E. Botanical discrimination and classification of honey samples applying gas chromatography/mass spectrometry fingerprinting of headspace volatile compounds. Food Chem. 2010, 121, 856-862. [CrossRef]

34. Karabagias, I.K.; Nikolaou, C.; Karabagias, V.K. Volatile fingerprints of common and rare honeys produced in Greece: In search of PHVMs with implementation of the honey code. Eur. Food Res. Technol. 2019, 245, 23-39. [CrossRef]

35. Karabagias, I.K.; Karabagias, V.K.; Badeka, A.V. The Honey volatile code: A collective study and extended version. Foods 2019, 8, 508. [CrossRef]

36. Xagoraris, M.; Revelou, P.K.; Dedegkika, S.; Kanakis, C.D.; Papadopoulos, G.K.; Pappas, C.S.; Tarantilis, P.A. SPME-GC-MS and FTIR-ATR spectroscopic study as a tool for unifloral common greek honeys' botanical origin identification. Appl. Sci. 2021, 11, 3159. [CrossRef]

37. Xagoraris, M.; Skouria, A.; Revelou, P.K.; Alissandrakis, E.; Tarantilis, P.A.; Pappas, C.S. Response surface methodology to optimize the isolation of dominant volatile compounds from monofloral greek thyme honey using SPME-GC-MS. Molecules 2021, 26, 3612. [CrossRef]

38. Xagoraris, M.; Chrysoulaki, F.; Revelou, P.-K.; Alissandrakis, E.; Tarantilis, P.A.; Pappas, C.S. Unifloral autumn heather honey from indigenous Greek Erica manipuliflora Salisb.: SPME/GC-MS characterization of the volatile fraction and optimization of the isolation parameters. Foods 2021, 10, 2487. [CrossRef]

39. Graikou, K.; Andreou, A.; Chinou, I. Chemical profile of Greek Arbutus unedo honey: Biological properties. J. Apic. Res. 2021. [CrossRef]

40. Orfanakis, E.; Markoulidakis, M.; Philippidis, A.; Zoumi, A.; Velegrakis, M. Optical spectroscopy methods combined with multivariate statistical analysis for the classification of Cretan thyme, multi-floral and honeydew honey. J. Sci. Food Agric. 2021, 101, 5337-5347. [CrossRef] [PubMed]

41. Xagoraris, M.; Revelou, P.K.; Alissandrakis, E.; Tarantilis, P.A.; Pappas, C.S. The use of right angle fluorescence spectroscopy to distinguish the botanical origin of Greek common honey varieties. Appl. Sci. 2021, 11, 4047. [CrossRef]

42. Karabagias, I.K.; Vlasiou, M.; Kontakos, S.; Drouza, C.; Kontominas, M.G.; Keramidas, A.D. Geographical discrimination of pine and fir honeys using multivariate analyses of major and minor honey components identified by 1H NMR and HPLC along with physicochemical data. Eur. Food Res. Technol. 2018, 244, 1249-1259. [CrossRef]

43. Kazalaki, A.; Misiak, M.; Spyros, A.; Dais, P. Identification and quantitative determination of carbohydrate molecules in Greek honey by employing 13C NMR spectroscopy. Anal. Methods 2015, 7, 5962-5972. [CrossRef]

44. Karabagias, I.K.; Louppis, A.P.; Karabournioti, S.; Kontakos, S.; Papastephanou, C.; Kontominas, M.G. Characterization and geographical discrimination of commercial Citrus spp. honeys produced in different Mediterranean countries based on minerals, volatile compounds and physicochemical parameters, using chemometrics. Food Chem. 2017, 217, 445-455. [CrossRef]

45. Karabagias, I.K.; Louppis, A.P.; Karabournioti, S.; Kontakos, S.; Papastephanou, C.; Kontominas, M.G. Characterization and classification of commercial thyme honeys produced in specific Mediterranean countries according to geographical origin, using physicochemical parameter values and mineral content in combination with chemometrics. Eur. Food Res. Technol. 2017, 243, 889-900. [CrossRef]

46. Karabagias, I.K.; Louppis, A.P.; Kontakos, S.; Drouza, C.; Papastephanou, C. Characterization and Botanical Differentiation of Monofloral and Multifloral Honeys Produced in Cyprus, Greece, and Egypt Using Physicochemical Parameter Analysis and Mineral Content in Conjunction with Supervised Statistical Techniques. J. Anal. Methods Chem. 2018, 1-10. [CrossRef] 
47. Drivelos, S.A.; Danezis, G.P.; Halagarda, M.; Popek, S.; Georgiou, C.A. Geographical origin and botanical type honey authentication through elemental metabolomics via chemometrics. Food Chem. 2021, 338, 127936. [CrossRef] [PubMed]

48. Louppis, A.P.; Karabagias, I.K.; Papastephanou, C.; Badeka, A. Two-way characterization of beekeepers' honey according to botanical origin on the basis of mineral content analysis using ICP-OES implemented with multiple chemometric tools. Foods 2019, 8, 210. [CrossRef] [PubMed]

49. Stefas, D.; Gyftokostas, N.; Couris, S. Laser induced breakdown spectroscopy for elemental analysis and discrimination of honey samples. Spectrochim. Acta-Part B At. Spectrosc. 2020, 172, 105969. [CrossRef]

50. Karabagias, I.K.; Casiello, G.; Kontakos, S.; Louppis, A.P.; Longobardi, F.; Kontominas, M.G. Investigating the impact of botanical origin and harvesting period on carbon stable isotope ratio values $(13 \mathrm{C} / 12 \mathrm{C})$ and different parameter analysis of Greek unifloral honeys: A chemometric approach for correct botanical discrimination. Int. J. Food Sci. Technol. 2016, 51, 2460-2467. [CrossRef] 